Agro-Science Journal of Tropical Agriculture, Food, Environment and Extension Volume 20 Number 2 (April 2021) pp. 9 - 13

ISSN 1119-7455

\title{
SOCIO-ECONOMIC ANALYSIS OF NON-TIMBER FOREST PRODUCTS: A CASE OF WRAPPING LEAVES IN OLUWA FOREST RESERVE, ONDO STATE, NIGERIA
}

\author{
${ }^{1}$ Olawuyi E.B., ${ }^{* 1}$ Odeyale O.C., ${ }^{2}$ Ugege B.H. and ${ }^{1}$ Adenuga D.A. \\ ${ }^{1}$ Department of Forestry Technology, Federal College of Forestry, Ibadan, Nigeria \\ ${ }^{2}$ Department of Agricultural Economics \& Management, Federal College of Forestry, Ibadan, Nigeria \\ *Corresponding author’s email: jumoceline81@gmail.com; bridgetonyenue@yahoo.com
}

\begin{abstract}
The significant role of Non-Timber Forest Products (NTFPs) cannot be over emphasized in nation building. Despite the tremendous benefits derived from the NTFPs in supporting the rural dwellers financially, it is perceived as less important to national development especially in developing countries. This study analyzed the economic benefits of non-timber forest products in Oluwa forest reserve, Ondo State with a view to encouraging sustainable forest management. Purposive and random sampling were used to select 213 respondents for the study. Descriptive statistics and the budgetary techniques analyses were used for the study. Results indicated that majority of the respondents were male $(56.10 \%), 30.00 \%$ were between the age of $30-39$ years, $78.10 \%$ were married, $55.90 \%$ had household size between $1-5$ people and $47.10 \%$ had secondary education. Major non-timber forest products identified in the study area include; wrapping leaves $(23.20 \%)$, fuel wood $(22.60 \%)$, bush meat (14.80\%), snails (9.70\%) and wild fruits $(7.70 \%)$. The study showed that respondents used more of wrapping leaves and fuel wood with average ranking of 0.84 and 0.83 respectively. The result showed a positive profit (\$20,700.00) for wrapping leaf business and returns $\$ 1.80 \mathrm{k}$ for every $¥ 1$ invested. The study calls for sustainable forest management of non-timber forest products to be taken up as a developmental strategy in the study area.
\end{abstract}

Key words: NTFPs, Oluwa forest reserve, rural dwellers, sustainable forest management, wrapping leaves

\section{INTRODUCTION}

Non-timber forest products (NTFPs) constitute an important aspect of sustainable economic growth, conservation and resources management. They refer to a wide array of substances or materials that come from the forest excluding timber (Shackleton and Pandey, 2014; Olawuyi et al., 2019). There are many plant resources that are derived from the forest, which include; wrapping leaves, fruits, nuts, essential oils, mushrooms, medicinal products, dyes, herbs, resins and even animal products such as honey and wild game. Other products may be produced with varying degrees of cultivation and domestication, either with a forest ecosystem or as part of a planted ecosystem such as an agro-forestry or forestry project (Olawuyi and Odeyale, 2019).

Non-timber forest products represent income opportunities from forest that do not involve cutting down trees for wood products. In forest with low timber production potential, non-timber forest products represent the major or potential source of income, traditionally used and appreciated by people of many cultures worldwide (Odeyale and Olawuyi, 2018). The significance of these products for sustainable economic growth, cultural endurance and environmental health is receiving increasing recognition by government and other official agencies (Bonet et al., 2009). Thaumatococcus danielli (Benn) is a non-timber forest species (Borokini et al., 2010) that can contribute to the rural economy of Nigeria but whose potentials have not been fully exploited for community development. It is a multi-purpose perennial herb that offers a wide assortment of uses for its leaves, fruits, stalks and roots (Arowosoge and Popoola, 2002). It is a naturally occurring plant growing in the wild. The fruit for instance was discovered to contain a sweet protein called thaumatin (Edens et al., 1982). Locally, Thaumatococcus danielli fruits are used for sweetening palm wine and sour foods. The aril of this plant is said to contain thaumatin; a non-toxic substance 1600 times sweeter than sucrose which is used to sweeten beverages, desserts, bubble gums among others (Yeboah et al., 2003; NAGRAB, 2008; Eniayeju, 2010). Some research work has been done on the economic potentials of this miraculous berry and the analysis of the plant as a pulp. All parts of Thaumatococcus danielli are useful, a feature which qualifies it as an economic plant. The by-product of mat weaving is used for producing local sponge for bathing. The leaves are used for thatching roofs and it can last for 2 years. The leaves are noted for wrapping of different kinds

Please cite as: Olawuyi E.B., Odeyale O.C., Ugege B.H. and Adenuga D.A. (2021). Socio-economic analysis of non-timber forest products: a case of wrapping leaves in Oluwa Forest Reserve, Ondo State, Nigeria. Agro-Science, 20 (2), 9-13. DOI: https://dx.doi.org/10.4314/as.v20i2.2 
of food. It can be used for wrapping unprocessed food like meats, kolanut, bitter cola etc.; semiprocessed foods like locust beans and processed foods like pounded yam, Amala (cooked yam flour), pap, beans among others (Ojekale et al., 2007; Adebisi-Adelani et al., 2010).

Trade in non-timber forest products provides a prospect in terms of income generation for rural household. Incomes are earned in communities where other cash income earning sources are limited (Shackleton and Pandey, 2014; Aluko et al., 2020). However, despite the significance of nontimber forest products to the rural dwellers and the nation economic development, there is no information on the profitability of wrapping leaves in the area. Therefore, this study estimated socioeconomic analysis of wrapping leaves, with a view to encouraging conservation of the species for sustainable forest management in the study area.

\section{MATERIALS AND METHODS}

\section{Description of the Study Area}

Ondo State is one of the most popular states in Nigeria with a total population of 401,147 (National population commission, 2006). The state is richly endowed with abundant forest resources. One of such resources is the Oluwa forest reserve which covers over $829 \mathrm{~km}^{2}$ (320 sqm). Oluwa forest reserve is located between latitude $6^{0} 49^{\prime}$ $23^{\prime \prime} \mathrm{N}$ and longitude $4^{0} 40^{\prime} 26^{\prime \prime} \mathrm{E}$ (National Mab Committee, 2014). It is part of the Omo-Shasha forest reserves. The three reserves contain some of the last remaining forest in the area. Although they are biologically unique, they are threatened by logging, hunting and agricultural activities.

\section{Sampling Procedure}

From the reconnaissance survey carried out, 12 major villages were identified around the Oluwa forest reserve. These include Afforestation camp, Ayetimbo, Ogunlepa, Araromi-Obu, Kajola, Leege, Orisunbare, Modebiayo, Makinde, Oloruntedo Ogunlepa and Onipetesi. Purposive sampling was used to select four villages which are: Afforestation camp, Makinde, Modebiayo and Oloruntedo based on their active involvement in NTFPs collection in the area. The population of these villagers was obtained from the National Population Commission of the State in 2019. Thus, projection of the 2019 population of each village was computed as:

$$
P n=\text { Poert... }
$$

where $P$ is final population, $P_{o}$ is initial population, $e$ is exponential, $r$ is growth rate at $3.5 \%$, and $t$ is time (i.e., $x-1991 ; x$ being the projection year).

However, the sampling intensity according to Diaw et al. (2002) was used to select respondents for the study. This indicated that $10 \%$ sampling intensity be used for population below 500, 5\% sampling intensity for population between 500 and
1000 , and $2.5 \%$ sampling intensity for population above 1000. Consequently, 60 copies of questionnaire were administered in Afforestation camp, 65 in Makinde, 22 in Modebiayo and 66 in Oloruntedo, make the total of 213 respondents.

\section{Data Collection}

Primary and secondary data were used for this study. The primary data was collected with the aid of structured questionnaire. Questionnaire was administered to the respondents after which they were retrieved. The questionnaire was designed to identify the non-timber forest products in the study area; identify the most prioritized non-timber forest products in the area and to investigate the profitability of the most prioritized non -timber forest products in the study area. However, secondary data were obtained from the National Population Commission result of 1991 (National Population Commission, 1991).

\section{Data Analysis}

Data collected were analyzed using descriptive statistics; the most prioritized non-timber forest products in the study area were analyzed following the procedure adopted by Adeola et al. (1994). This procedure indicated that for one to establish the final position of a non-timber forest product species in the ranking exercise, the following parameters were calculated:

(1) Number of times the non-timber forest product was mentioned

(2) Mentioned value

(3) Average ranking (for a particular product) by respondents

(4) Rank value

(5) Final assigned value ................................ (e); where;

(1) The number of times a particular non-timber forest product was mentioned (a) was computed to obtain its mentioned value (b).

(2) Average ranking (c) of each non-timber forest product was calculated as a function of the sum of its assigned ranking by the respondents divided by the total number of the respondents.

(3) The rank value (d) was obtained by tabulating and ordering of the position of the individual non-timber forest products.

(4) (4) Assigned value (e) was determined by adding up mentioned value and rank value and then dividing by 2 , i.e., $e=b+d / 2$

Based on this, the top prioritized non-timber forest product was selected for further study. The profitability of selected non-timber forest product in the study area was analyzed using budgetary techniques. Budgetary techniques involve the estimation of the cost and returns associated with the collection and marketing of selected non-timber forest products. The profit for the selected nontimber forest product was calculated using: 


$$
\begin{aligned}
n= & R-(V C+F C) \\
& V C=r i x i \ldots \ldots \\
& G M=R-V C \\
& T C=V C+F C
\end{aligned}
$$

Where N-Net income R-Gross revenue VCVariable cost ri-Price of variable input used $\mathrm{xi}$ Quantity of variable input FC-Fixed cost GMGross margin TC-Total cost.

The benefit cost ratio (BCR) was also calculated; BCR shows the relationship between the costs and benefits of a proposed project. If the BCR $>1$, the business is economically satisfactory, if $\mathrm{BCR}=1$, then there is economic break even in the business while if $\mathrm{BCR}<1$, the business is not economically satisfactory and the business is not feasible.

Benefit Cost Ratio $=\left\{\sum_{t=1}^{n} B t(1+r)-\right.$ $\left.t / \sum_{t=1}^{n} C t(1+r)-t\right\} \geq$

BCR-Benefit stream/ Cost stream;

where $B_{t}$ is benefit at time $t, C_{t}$ is measure of cost at time $t, t$ is time, and $r$ is discount rate.

\section{RESULTS AND DISCUSSION}

Socio-Demographic Characteristics of Respondents The result in Table 1 shows the socio-economic characteristics of respondents in the study area. Out of a total of 213 copies of questionnaires distributed, $155(72.8 \%)$ were retrieved and used for analysis. However, the remaining 58 questionnaire were found missing as a result, could not be retrieved. The result indicated that $56.1 \%$ of the respondents in the study area were male while $43.9 \%$ of the respondents were female. This showed that there were more males than females involved in collection of NTFPs in the reserve.

This might be due to the fact that women were mostly involved in domestic work while the men engage in more tasking jobs in providing for the family needs. This corroborated the findings of Adebisi-Adelani et al. (2010) and Odeyale and Olawuyi (2018) who reported that males resilient to stress management make it possible for them to engage in more tedious work than their female counterpart. The result on age distribution of respondents revealed that the mean age of respondents were 40.40 years. Majority $(30.0 \%)$ of respondents were within the ages of 30-39 years, respondents within ages of 40-49 years with $27.10 \%$ while those within the ages of 60 and above recorded the least percentage $(14.80 \%)$. This is an indication that most of the respondents are within the active group and can still be able to source for income in order to sustain livelihood. This was in line with Adejumo et al. (2016) who stated that the highly productive age involved in agricultural and forestry activities fall within the age group of 31-50 years. The result further revealed that $78.10 \%$ of the respondents were married indicating that respondents have responsibilities of caring and providing for their families. This however supported the findings of Olawuyi and Agbeja (2018) who stated that a high percentage of the rural populations are married.

The respondents had a mean house-hold size of 6 (Table 1). Households of $1-5$ persons recorded the highest percentage with $55.90 \%$ while household between 11-15 persons had the least percentage of $2.00 \%$. Household size is a function of more commitment in the family and thus linked with the large expected income of the family for a better standard of living. Awe et al. (2011) noted that non-timber forest products collection and gathering is a collective effort which requires more hands hence the use of family labour is required. Also, most of the respondents $(47.10 \%)$ had secondary education; this was followed by those with primary education with $29.10 \%$ while those who had no formal education recorded the least at $11.00 \%$. The result on education implied that a large percentage of the respondents have basic education at primary and secondary levels. It thus supported the findings of Olawuyi and Agbeja (2018), that formal education is not a major criterion needed for the forest dependent communities but their utmost concern is the easy, cheap and readily available farm practice and non-timber forest products

\begin{tabular}{|c|c|c|c|}
\hline $\begin{array}{l}\text { Socio-demographic } \\
\text { characteristics }\end{array}$ & Frequency & Mean & Percentage \\
\hline \multicolumn{4}{|l|}{ Gender } \\
\hline Male & 87 & & 56.10 \\
\hline Female & 68 & & 43.90 \\
\hline Total & 155 & & 100.00 \\
\hline \multicolumn{4}{|l|}{ Age (years) } \\
\hline $20-29$ & 33 & & 21.30 \\
\hline $30-39$ & 45 & & 29.90 \\
\hline $40-49$ & 42 & & 27.10 \\
\hline $50-59$ & 23 & & 14.80 \\
\hline $60-79$ & 12 & & 7.80 \\
\hline Total & 155 & 40.40 & 100.00 \\
\hline \multicolumn{4}{|l|}{ Marital Status } \\
\hline Single & 20 & & 12.90 \\
\hline Married & 121 & & 78.10 \\
\hline Divorced & 3 & & 1.90 \\
\hline Widow/Widower & 11 & & 7.10 \\
\hline Total & 155 & & 100.00 \\
\hline \multicolumn{4}{|l|}{ Household Size } \\
\hline $1-5$ & 85 & & 54.80 \\
\hline $6-10$ & 64 & & 41.30 \\
\hline $11-15$ & 6 & & 3.90 \\
\hline Total & 155 & 6.00 & 100.00 \\
\hline \multicolumn{4}{|l|}{ Educational Level } \\
\hline No Formal Education & 17 & & 11.00 \\
\hline Primary Education & 46 & & 29.10 \\
\hline Secondary Education & 73 & & 47.10 \\
\hline Tertiary Education & 19 & & 12.20 \\
\hline Total & 155 & & 100.00 \\
\hline
\end{tabular}
gathering in order to sustain livelihood.

Table 1: Distribution of the respondents for the study in Oluwa Forest Reserve 


\section{Identification of Non-Timber Forest Products Usage in the Study Area}

The result in Table 2 shows the non-timber forest products identified in the study area. The result showed that wrapping leaves had the highest percentage $(23.20 \%)$, closely followed by fuel wood $(22.60 \%)$, with the least $(1.30 \%)$ from kolanut. The higher percentage of wrapping leaves recorded might be due to the fact that most people residing in the study area use the product for special delicacies such as wrapping finger foods, beans pudding etc. The result further showed that the area is highly enriched with various varieties of nontimber forest products which serve the needs of the inhabitants. The findings were in line with Olawuyi and Agbeja (2018) who stated that non-timber forest products in broad sense are any biological resources collected from wild by rural people for direct consumption and income generation.

\section{Ranking Analysis of Non-Timber Forest Products in the Study Area}

The result in Table 3 reveals the most prioritized non-timber forest products in the study area. Wrapping leaves have the highest average ranking of 0.84 , followed by fuel wood (0.83), snail (0.64), bush meat (0.62), walnut and medicinal plant $(0.40$ each), fish (0.33), wild fruits (0.29), mushroom $(0.29)$ and kolanut $(0.18)$. The high average ranking observed in wrapping leaves was because wrapping leaves are widely collected and useful by the people of the community and they are collected mostly for sale unlike fuel wood which was mostly collected for the generation of heat for domestic cooking.

\section{Profitability Analysis of Wrapping Leaves in the Study Area}

The result in Table 4 showed the costs and returns on collection of wrapping leaves in Oluwa forest reserve. Since wrapping leaves was showed as the commonly used NTFPs in the area study. The mean total variable cost (TVC) incurred in the collection per bundle of $50 \mathrm{~kg}$ was $25,800.00$, (this included
Table 2: Non-timber forest products identified in the study area

\begin{tabular}{lll}
\hline NTFPs identified & Frequency & Percentage \\
\hline Firewood & 35 & 22.6 \\
Wrapping leaves & 36 & 23.2 \\
Bush meat & 23 & 14.8 \\
Snail & 15 & 9.7 \\
Walnut & 6 & 3.9 \\
Medicinal herbs & 11 & 7.1 \\
Wild fruits & 12 & 7.7 \\
Mushrooms & 10 & 6.5 \\
Fish & 5 & 3.2 \\
Kolanut & 2 & 1.3 \\
Total & 155 & 100 \\
\hline
\end{tabular}

Source: Field Survey, 2019

charges paid for collection of NTFPs in the reserves, labour employed as well as for transportation to the location). The mean total fixed cost incurred in the collection was $\$ 3137.63$. The result showed that the average gross margin obtained by individual respondent in the study area was estimated at N20,700.00. This implied that wrapping leaves marketing is profitable in the study area. Thus, the overall margin which gives the profit per cost incurred during the business transaction was considered by the way of estimating benefits cost ratio (BCR). The study estimated BCR of 1.80 . This means that wrapping leaves business returns positive margin indicating the viability of the business. This indicated that for every one Naira (N1) spent by the respondent there would be return of $80 \mathrm{k}$. The result therefore, revealed that wrapping leaves marketing is profitable in the study area. This was attributed to the fact that collection of this product was almost free (though collectors are made to pay little charges so as to gain entry into forest reserves) with little or zero processing and they are readily available in the area. Olawuyi et al. (2019) observed that gathering and use of non-timber forest products can be a mechanism for poverty alleviation and local development.

Table 3: Most prioritized non-timber forest products (NTFPs) in the study area

\begin{tabular}{|c|c|c|c|c|c|}
\hline \multirow{2}{*}{ NTFPs } & \multirow{2}{*}{ Frequency } & \multicolumn{2}{|c|}{ Mentioned Average } & \multirow{2}{*}{ Rank value } & \multirow{2}{*}{ Assigned value } \\
\hline & & value & ranking & & \\
\hline Wrapping leaves & 36 & 1 & 0.84 & 3 & 2.00 \\
\hline Fuel wood & 35 & 1 & 0.83 & 11 & 6.00 \\
\hline Snail & 13 & 2 & 0.64 & 2 & 2.00 \\
\hline Bush meat & 23 & 3 & 0.62 & 7 & 5.00 \\
\hline Walnut & 6 & 4 & 0.40 & 5 & 4.50 \\
\hline Medicinal plant & 13 & 4 & 0.40 & 10 & 7.00 \\
\hline Fish & 5 & 6 & 0.33 & 1 & 3.50 \\
\hline Wild fruits & 12 & 7 & 0.29 & 4 & 5.50 \\
\hline Mushroom & 10 & 7 & 0.29 & 6 & 6.50 \\
\hline Kolanut & 2 & 9 & 0.18 & 12 & 10.50 \\
\hline
\end{tabular}


Table 4: Profitability of wrapping leaves in Oluwa Forest Reserve

\begin{tabular}{ll}
\hline Item & Cost (\#) \\
\hline A Variable cost & \\
$\quad$ Price collection & 8000.00 \\
$\quad$ Labour & 6000.00 \\
$\quad$ Transportation & 11800.00 \\
$\quad$ Total variable cost & 25800.00 \\
B Fixed cost & \\
Depreciation on Cutlass & 1302.63 \\
Depreciation on Knife & 219.73 \\
Depreciation on Sack bag & 208.33 \\
Depreciation on Basket & 637.50 \\
Depreciation on Rope & 169.44 \\
Depreciation on Tray & 600.00 \\
Total fixed cost & 3137.63 \\
C Total cost ( A+B) & 28937.63 \\
D Total income/ revenue & 46500.00 \\
E Gross margin ( D - A) & 20700.00 \\
F Net profit ( D - C) & 17562.37 \\
G Average gross margin & 460.00 \\
H Benefit cost ratio (BCR) & 1.80 \\
\hline Source: Field Survey, 2019 &
\end{tabular}

Source: Field Survey, 2019

\section{CONCLUSION}

The important roles played by NTFPs in livelihood of rural households cannot be over-emphasized. Majority of rural households depends on the products to meet some part of their nutritional, health, house consumption or other needs. People dwelling in the study area collect more of wrapping leaves than other non-timber forest products available in the area. Wrapping leaves was mostly collected for sales and for wrapping foods such as beans pudding (moimoi), morsel foods and kolanut. The wrapping leaves business was profitable by returning $\$ 1.80$ for every one naira ( 1 ) spent on the business. Therefore, the study calls for sustainable forest management of non-timber forest products as a developmental strategy in the reserve to ensure the continuous availability of these products for rural sustenance.

\section{REFERENCES}

Adebisi-Adelani O., Adeoye I.B., Olajide-Taiwo F.B., Usman J.M., Agbarevoh P. and Oyedele O.O. (2010). Gender analysis of production potential and constraints of Thaumatococcus danielli in Ekiti State. Cont. J. Agric. Sci., 4, 54-59

Adejumo A.A., Aluko O.J., Marizu J.T. and Ajanaku A.O. (2016). Adaptive strategies of deforestation employed by non- timber forest products collectors in Okomu Forest Reserve, Edo State, Nigeria. Commonwealth Forestry Association (CFA) Conference Proc., 1, 37-41

Adeola A.O., Ayelaagbe I.O.O., Ladipo, D.O. and Popoola L. (1994). Survey of multipurpose tree species for prioritization in humid lowland of Nigeria. Assigned value method report to ICRAF, FEB 1994. p.11

Aluko O.J., Adejumo A.A. and Bobadoye A.O. (2020). Adaptive strategies to deforestation among nontimber forest products (NTFPS) collectors across gender line in Oluwa Forest Reserve area of Ondo State, Nigeria. Agro-Science, 19 (2), 48-52.DOI: https://dx.doi.org/10.4314/as.v19i2.8

Arowosoge O.G.E. and Popoola L. (2002). Economic analysis of Thaumatococcu sdanielli (Benn), Miraculous Berry in Ekiti State, Nigeria. Int. J. Food, Agric. Environ., 4 (1), 264-269
Awe F., Osadebe C.O., Imoagene E., Fashina A.Y., Eniola T.S. and Adeleke E.O. (2011). Assessment of rural household objectives for gathering non-timber forest products in Kogi state, Nigeria. Afr. J. Environ. Sci. Technol., 5 (2), 143-148

Bonet J.A, Oliach D., Fischer C., Olivera A., Aragon J.M. de and Colinas C. (2009). Cultivation method of the Black Truffle, the most profitable Mediterranean non-wood forest products: A state of the art review. Modeling Valuing \& Managing Mediterranean Forest Ecosys. for Non-Timber Goods \& Services, 57, 57-71

Borokini T.I., Okere A.U., Giwa A.O., Daramola B.O. and Odofin W.T. (2010). Biodiversity and conservation of plant genetic resources in field gene bank of the National Centre for Genetic Resources and Biotechnology, Ibadan, Nigeria. Int. J. Biodiv. Conserv., 2 (3), 37-50

Diaw K.D., Blay and Adu-Anning C. (2002). Socioeconomic survey of forest fringe communities; Krokosua Hills Forest Reserve. A Report Submitted to the Forestry Commission of Ghana. pp 32-35

Edens L., Heslinga L., Klok R. et al. (1982). Cloning of DNA encoding the sweet tasting plant protein thaumatin and its expression in Escherichia coli. Gene, 18 (1), 1-12. DOI: 10.1016/0378-111

NAGRAB (2008). Plant Genetic Resources for Food and Agriculture (1996-2008), National Centre for Genetic Resources and Biotechnology, p.16

National Mab Committee (2014). Socio-economic survey of eleven communities within Omo Biosphere Reserve, Ogun State, Nigeria. A report submitted to UNESCO Regional Office in Abuja. Pp 3

National Population Commission (1991). Nigerian Census 1991. National Population Commission, Lagos

National Population Commission (2006). Nigeria National Census: Population Distribution by Sex, States, LGAs and Senatorial District: 2006 Census Prority Tables (Vol. 3)

Odeyale O.C. and Olawuyi E.B. (2018). Socio-economic impact of non-timber forest products in income generation for sustainable forest management in Gambari Forest Reserve, Oyo State, Nigeria. Sci. Res. $J .$, VI (X), 35-43

Ojekale A.B., Makinde S.C.O., Osileye O. (2007). Phytochemistry and antimicrobial evaluation of Thaumatococcus danielli, Benn. (Benth.) Leaves. Nigerian Food Journal, 25, 1-5

Olawuyi E.B., Adejumo A.A. and Faleyimu O.I. (2019): Socio-economic impact of non-timber forest products in rural household income in Osho forest reserve, Oyo state, Nigeria. Agric. Sci. Res. J., 9 (3), 27-34

Olawuyi E.B. and Agbeja B.O. (2018). Socio-economic impact of gazetted forest reserves on forest dependent communities in Edo State, Nigeria. Commonwealth Forestry Association (CFA) Conf. Proc., 2, 51-60

Olawuyi E.B. and Odeyale O.C. (2019). Socio-economic analysis of agroforestry practices in Odeda Local Government Area, Ogun State. J. Sust. Environ. Manag., 11, 45-48

Shackleton C.M. and Pandey A.K. (2014). Positioning non-timber forest products on the right development agenda. Forest Policy Econ., 38, 1-7

Yeboah S.O., Hilger T.H. and Krochcel J. (2003). Thaumatococcus danielli (Benn.) Benth.- a natural sweetener from the rain forest zone in West Africa with potential for income generation in small scale farming, Applied Sci. 6, 854-859 